\title{
The Container Image Schema as the Conceptual Basis of English Adjectives' Semantics
}

\author{
Marina B. Antonova \\ National Research University Higher School of Economics
}

\begin{abstract}
Correspondence concerning this article should be addressed to Marina B. Antonova, School of Foreign Languages / Department of English for Economic and Mathematical Studies, National Research University Higher School of Economics, 34 Tallinskaya Ulitsa, rom 420, Moscow, 123458, Russian Federation.

E-mail: mbantonova@hse.ru
\end{abstract}

This paper focuses on the cognitive foundation of the semantics of English adjectives that denote mental and moral characteristics of human beings. Research into these adjectives seems a challenging task because they denote abstract qualities that cannot be perceived through vision, hearing, or touch; and here a question arises: How are abstract qualities interpreted in English encoded through adjectives? To answer it, this study follows the idea of two-level semantics, i.e. word semantics is treated as a two-level phenomenon that comprises the semantic (external) level and the conceptual (deep) one. This study is the first to address adjectival semantics from this perspective. Here a novel approach to revealing the cognitive foundation of adjectives is introduced: given that adjectives originated from old syncretic items and a word cognitive model forms at the moment of word creation, cognitive models underlying adjectives' semantics are unearthed via analysis of their etymological data. Our contribution is two-fold. First, the approach has revealed that the image schema CONTAINER guides semantics of an array of various adjectives independent of their morphemic structure or date of origin. The examples demonstrate that abstract human qualities are interpreted via the following container features: boundary, container substance, size, hardness/softness of a container shell, etc. The semantics of affixed or compound adjectives appear to stem from the integration of concepts represented by an affix and a root or two roots, respectively. Second, the findings show that the value given to every container feature appears to predetermine the evaluation conveyed by an adjective. Container features tend to possess ambivalent value, realizing the positive or negative one due to the interaction with a frame in which the CONTAINER is incorporated, therefore the same polysemantic adjective may develop both positive and negative meanings. To reveal the whole inventory of cognitive models that govern adjectival semantics in English, further research needs to be conducted.

Keywords: conceptual basis, image schema, semantics, frame, evaluation meaning, adjective, English

\section{Introduction}

One of the most revolutionary ideas introduced by cognitive linguistics concerns the distinction between the semantic, or language, and the conceptual levels. Initially, this idea was developed within the framework of the Two-level Semantics theory pioneered by Bierwisch (Bierwisch, 1983; Bierwisch \& Lang, 1987; Bierwisch \& Bosch, 1995). The theory argues "the conceptual nature of the meanings conveyed by natural language expressions" (Lang \& Maienborn, 2011, p. 709). In other words, the semantics of a language item is treated as a complex phenomenon: the meanings that a language item conveys rest on a certain conceptual basis that accounts for them. The conceptual basis is structured by cognitive models (Lakoff, 1987; Evans, 2006; Jackendoff, 2011; Lang \& Maienborn, 2011; Cruse, 2017; Boldyrev, 2016).

Being part and parcel of culture, every language operates with its own systems of concepts and cognitive models to regulate the construction of associated meanings. Since "the connection between words and the outside world is mediated through concepts" (Cruse 2017, p. 241), to unearth the conceptual bases of various language 
items and categories seems an important task. To the best of the author's knowledge, however, few studies have been conducted in this field so far; in particular, conceptual bases were modelled for English idioms (Zykova, 2018), and euphemisms belonging to such Romano-Germanic languages as Italian, Spanish, French, English, and German (Porohnickaya, 2014).

As for adjectives, and English ones are no exception, they have not yet been investigated in this respect. However, adjectival conceptual basis modelling seems to be a challenging aspect of linguistic research, bearing in mind the ambiguous character of the adjectival category, which still remains the most debatable among linguists. By way of illustration, English adjectives have been investigated from various perspectives: structural linguistics, generative linguistics, and cognitive semantics. Researchers state different, even polar opinions on the adjectival status, from classifying qualitative and relative adjectives as two separate parts of speech to including adjectives into the verb or adverb categories (Chafe, 1970; Givon, 1970; Lakoff, 1970; Dixon, 1982; Baker, 2003). Moreover, adjectives were characterized as "a notorious swing category" (Givon, 2014, p. 13-14). Cross-linguistically, the category referred to as "adjectives" varies more significantly than the noun or verb ones. In some languages, and in English, the adjectival category constitutes a large, open class of words, while "in a number of other languages, such as Hausa, there is a small closed class of words... In yet other languages, such as Chinese, it is claimed that adjectives do not exist" (Croft, 2003, p. 183). Recent years have seen similar discussions; in particular, the distinction between adjectives and determiners has been justified for Serbian (LaTerza, 2015), a double semantic value of the Gothic adjective sama has been stated (Ratkus, 2018), and a mixed category combining morphemic and syntactic peculiarities of nouns and adjectives has been singled out in the Tungus language (Nikolaeva, 2008). The ambiguity of adjectives leads to difficulty in their identification in texts, proper use, and proper adjective ordering (Abd Rahim, 2013; Sosnina, 2015; Berg, 2019; Trotzke \& Wittenberg, 2019). Although the dominant opinion is that adjectives are not a universal language category, researchers agree that "every language seems to be equipped with adjectival concepts" (Pustet, 2006, p. 61).

Adjectives constitute the bulk of English vocabulary, playing an essential role in expressing our emotions, feelings, and attitudes, which has compelled computational linguistics to thoroughly investigate this language category. Researchers have argued that all adjectival peculiarities are substantiated by their nature (Cristani et al., 2018). This view seems quite reasonable since difficulties in determining the categorial features of adjectives may be linked to their syncretic origin, which also makes it important to gain insight into the adjectival conceptual basis.

Initially, quality was not encoded via adjectives; at the pre-logical reasoning stage qualities were comprehended not individually but inseparably from their referents. Properties of referents comprised unique combinations that allow the recognition of certain referents. Old words could function as denominations of both an object (referent) and its qualities (Kacnel'son, 2001, p. 413; Zhirmunskij, 1976, p. 210). The assumption that the Proto-Indo-European language did not differentiate between the noun and the adjective is substantiated by modern compound words composed by two nouns (noun+noun), with the first constituent playing the role of an attribute (Potebnya, 1968, p. 62; Klimov, 1977, p. 215; Gamkrelidze, 1984, p. 279). The distinction between the entity (object) and its properties (qualities) resulted in the formation of a new lexico-grammatical category - the adjective. This consecutiveness of language category formation can be evidenced by the fact that children acquire the names of objects before the names of their qualities (Hiramatsu et al., 2010). Moreover, there exists a certain consecutiveness of adjective acquisition by children (Weicker \& Schulz, 2019).

Alongside the theory of the noun origin of adjectives (Jespersen 1951; Zhirmunskij, 1976; Potebnya, 1926; Kacnel'son, 2001; Kubryakova, 2008, and others), other points of view exist on this issue: the halophrastic approach considers phrases, not nouns, as a primary language item (e.g. Piaget 1926; Schuchardt 1928; Gans 1981).

According to his typological research, Dixon has determined the nominative area of adjectives, subdividing them into core and peripheral semantic types. The core semantic types of adjectives cover DIMENSION, AGE, VALUE, COLOUR, while the peripheral ones denote PHYSICAL PROPERTY, HUMAN PROPENSITY, and SPEED (Dixon, 2004, p. 3-5).

The present study aims at modelling the conceptual basis of English adjectives denoting such human propensities as mental and moral ones. 
The adjectival categories of mental and moral characteristics have been chosen for the following reasons: first, they nominate essential human characteristics that began to be recognized before the Old English period; second, these adjectives denote abstract qualities that cannot be perceived through the senses of sight, hearing, smell, or touch but manifest themselves indirectly in human behavior, reasoning, and activity. Maturana and Varela (1992) stated that "we have language, there is no limit to what we can describe, imagine, and relate" (p. 212), but finding out how these abstract qualities are expected to be verbalized seems a challenging task. Third, given these adjectives convey evaluation - positive or negative, they reflect both the culture's evaluation standards and a speaker's interpretation of the performed quality. The contribution of this study is, therefore, twofold: the cognitive basis of English adjectives denoting abstract human beings' qualities is modelled and the influence of the cognitive basis on the evaluation meaning of the adjectives is considered.

\section{Method}

\section{Theoretical Background}

The following sections demonstrate the method and procedure for modelling the conceptual basis of the adjectives and dwell upon one of the major ways that mental and moral characteristics of human beings appear to be interpreted in English, namely via the CONTAINER image schema. According to Johnson, who introduced this term, image schema implies "a recurring dynamic pattern of our perceptual interactions and motor programs that gives coherence and structure to our experience" (Johnson, 1987, p. xiv). It should be mentioned that CONTAINER belongs to the major image schemas (Hampe, 2005, p. 2). The theory of image schemas is widely utilized in various cognitive studies (e.g. Alessandroni, 2017; Dancygier, 2017; Senkbeil, 2017; Martinez et al, 2018; Ioannou 2018; Vernillo, 2019), and it has proved to be of great application potential, even inspiring new research in the area of human-computer interactions (Hurtienne, 2017).

Being anthropocentric in nature, our conceptual systems ultimately depends on humans' physical and cultural experiences (Lakoff, 1987, p. xiv). Evans argues that "our embodiment is directly responsible for" the ways we perceive and interpret the world and the understanding of space boundaries emerges from human beings' "ongoing embodied experience" (Evans, 2006, pp. 177, 185). Since our physical bodies are "bounded and set off from the rest of the world by the surface of our skins," they can be treated as containers with "an in-out orientation" that is projected "onto other physical objects that are bounded by surfaces" or in the case they are not, "we impose boundaries marking off territory". In fact, "there are few human instincts more basic than territoriality" (Lakoff \& Johnson, 2003, p. 30). In fact, CONTAINER reflects certain spatial relations, but space awareness and awareness of oneself within space belong to the oldest and most fundamental ideas (Meletinskij, 1976; Ivanov, 1992; Podosinov, 1999). Kubryakova reasoned that the concept of container is ubiquitous both from ontological and philosophical perspectives (Kubryakova, 1999, p. 7).

The CONTAINER image schema can be extended to a large number of abstract concepts (Lakoff, 1987, p. 272), in particular, to that of the mind: "Mind is a container" (Lakoff \& Johnson, 2003, p. 149). In turn, ideas and knowledge are interpreted as discrete material objects that can be placed into a container, thus presenting a container substance: "Ideas are objects" (Lakoff \& Johnson, 2003, p. 31). In accordance with this, the CONTAINER image schema, although it should be treated as an integral whole, includes the following structural elements: INTERIOR/CONTAINER SUBSTANCE, BOUNDARY, and EXTERIOR CONTAINER (Lakoff, 1987, p. 272).

\section{Materials}

The adjectives for the current research have been gathered from The Original Roget's Thesaurus of English words and phrases (1987). Adjectives denoting mental characteristics of human beings belong to the sections "Mental" and "Intellect". As for moral qualities, adjectives encoding them may be found in the following sections: dueness, ethics, friendship, innocence, justice, kindness, love, modesty, pity, probity, sociability, virtue, arrogance, cunning, deception, enmity, improbity, injustice, jealousy, hatred, pride, selfishness, undueness, unsociability, vice, etc. The number of adjectives denoting mental and moral characteristics total 409 and 426 respectively.

Remarkably, words of negative evaluation predominate over those of positive meaning: mental characteristics - 233 vs 176 adjectives, moral characteristics - 267 vs 159 adjectives. In terms of derivation, the adjectives 
under study may include only one stem, therefore possessing one semantic centre, or two stems in the case of compounds, therefore comprising two semantic centres. Analysis of such structurally different adjectives can provide reliable and valid conclusions regarding the conceptual basis of these English adjectives' semantics.

\section{Procedure}

Given adjectives' ontogenesis, namely their stemming from a syncretic word, and the fact that the conceptual basis of word semantics forms at the moment of word creation, an analysis of adjectival etymological data could become the starting point of their conceptual basis modelling. To demonstrate the process of revealing the conceptual basis of adjectival semantics, let us consider the following example. Etymological data attest that the adjective accomplished XV c. ${ }^{1}$ is derived from the verb accomplish, which originates from the Old French acompliss- originating from the verb acomplir, from the Vulgar Latin *accomplere, from complere 'to fill', formed by the prefix com- and the root plere 'to fill', which goes back to the Proto-Indo-European root *pele-1 'to fill' (OED). The action of filling implies the mandatory presence of some container that is filled; consequently, in this case, the acquisition of knowledge or skills is interpreted as filling a container - the mind, thus bringing out the characteristics of the inner part of a container, or its interior.

Similar associations gave rise to the adjectives proficient, qualified, and affectionate, which came into English in the XVI c., originating from the Proto-Indo-European ${ }^{2}$ root * $d h-/{ }^{*} d h \bar{e}$ - 'to set, put'3 (OED; Vaan, 2008, p. 198199; Watkins, 2000). Insofar as the adjective affectionate is concerned, the heart is viewed as a container, while love and affection are associated with objects put inside.

Quite a number of adjectives characterizing human beings' mental activity have stemmed from the PIE root "gno- 'to know': keen Old English, acquainted XV c., canny XVI c., knowing XVII c., knowledgeable XIX c. (OED). If a person knows something, it means he/she has cumulated some thoughts, knowledge, or skills, and hence some thoughts, knowledge, or skills are perceived as objects that have been placed in the mind - a container.

Adjectives derived with the help of negative affixes form their semantics due to the integration of the concepts represented by the root and the affix. Meanings antonymous to the discussed above result from the integration of the concept CONTAINER represented by the roots and the concept ABSENCE represented by the affixes un-, -less: unknowing XIV c., unacquainted XVI c., unqualified XVI c., unaccomplished XVIII c., unaffectionate XIX c., affectless XX c., and unknowledgeable XX c. This conceptual integration creates the image of an empty container, in terms of which the deficiency in knowledge and skills or fondness and tenderness is described. Another example here is the adjective ignorant XIV c., which originates from the Latin ignorantem (nominative ignorans), from ignorare, from in- 'not' + Old Latin gnarus 'aware, acquainted with', from the Proto-Latin suffixed form "gno-ro-, from PIE *gno-(OED), which again forms an image of an empty container.

Roots of some adjectives go back to the PIE *dheu-1 'dust, vapor, smoke' or to the PIE roots meaning 'thick', for example: dull XIII c., doltish XVI c., dozy XX c. originate from PIE *dheu-1; thick XVI c. originates from PIE *tegu- 'thick'; and dense XIX c. originates from PIE *dens- 'thick' (OED; Vaan, 2008, p. 167). The logic behind these associations may be substantiated by people's experience that evidences that every container holds its own specific substance, which secures containers' functions. So obstruction of the intellectual process may be seen to be caused by an improper extremely dense container substance.

As for compound adjectives, their semantics also stems from integrated concepts but in this case is represented by two constituents of a compound. The head element of compounds may frequently convey the idea of a container in quite an explicit way, for example, dull-headed XVI c. airheaded 1970, fat-brained XVI c., hardhearted XIII c., stone-hearted XVI c. and so forth.

Further, implementation of the proposed method in modelling the conceptual basis of the adjectives in question will be demonstrated and other container characteristics involved in its formation will be described.

\footnotetext{
The date after the word indicates the time of its first known use in the discussed meaning as attested in The Oxford English Dictionary (1989).

2 henceforth - PIE.

3 In light of space limitations, from this point on the etymological data are given in a reduced form.
} 


\section{Analysis of the Adjectives Denoting Mental and Moral Human beings' Characteristics}

Given that states are conceptualized as containers (Lakoff \& Johnson, 2003, p. 31), meditating and being engrossed in thought can also be considered as filling container, while the absence of thought or forgetfulness are interpreted as empty containers: mindless Old English, mindful XIV c., unmindful XIV c., mental (inf. 'insane') XX c. go back to PIE *men- 'to think'; thoughtful XIII c., thoughtless XVI c., thinking XVII c. originate from PIE "tong- 'to think' (OED); and rational XIV c., irrational XIV c. go back to PIE *re- 'to think' (OED; Vaan, 2008, p. 519-520).

It is worth emphasizing that Wierzbicka labels the concepts THINK and KNOW as mental predicates belonging to basic human concepts, or semantic primitives, which are verbalized in various ways in different languages (Wierzbicka, 1996, p. 35).

Although CONTAINER acts as an integral image (image schema), in some cases different conceptual constituents of the image might come into focus. Some human qualities are nominated via the association with the container BOUNDARY. Thus, for instance, an area where people dwell, whether it is a house, town, or state, is enclosed with real physical boundaries and thus it can be referred to as a container. Dwellers in any particular area must obtain the necessary knowledge regarding its laws, standards of behavior, and traditions, which enables them to act under various circumstances properly: politic XV c. (archaic) 'prudent, sagacious' originates from PIE *tpolh'citadel; enclosed space, often on high ground, hilltop' (OED).

Societies impose certain limits for speaking about one's own merits in public and a person knowing these limits is estimated positively: modest XVI c. originates from PIE *med-1'to measure' (OED; Vaan, 2008, p. 384; Watkins, 2000; Pokorny, 1959, p. 705-706). Conversely, a person going beyond 'the boundary' of ethical norms is characterized negatively: immodest XVI c.

A person capable of understanding other people and showing compassion with them is seen as having easily penetrated the container shell, or having gone through boundaries: ruthful XIII c. (archaic) 'feeling sorrow or pity' originates from PIE "kreue-2 'to push, strike'; feeling XVII c. originates from PIE *pal- 'to touch, shake, strike softly' (OED). On the contrary, a hard shell makes an impervious barrier for external events and people's emotions: ruthless XIV c., unfeeling XVI c.; callous XVII c. originates from PIE "kal-1 'hard' (Pokorny, 1959, p. 523-524); hard Old English 'showing no kindness or sympathy', hardened XIV c. originates from PIE *kar-/ker'hard'; remorseless XVI c. goes back to PIE *mer-2 'to harm' (OED).

Ideas, notions, and problems that are to be understood may be interpreted as certain EXTERIOR containers penetrated by the mind. In this case, the mind becomes an instrument that beats or cuts in order to finally destroy the container shell and to cross its boundaries, for example: studious XIV c. originates from PIE *(s)teu-1 'to stick, knock, beat' (OED; Pokorny, 1959, p. 1032). In his commentary on the PIE root *(s)kel-1 'to cut', Watkins points out that human cognitive activity is compared to this quite concrete, physical operation (Watkins, 2000). Likewise, for the English language, Lakoff and Johnson (2003) single out the conceptual metaphor "Ideas are cutting instruments" (p. 49). The semantics of a large number of adjectives has formed on the basis of this interpretation of mind, for example: sharp-witted XVI c., razor-sharp XIX c.; shrewd-brained XVII c., shrewdheaded XIX c., shrewd-pated XVII c. - shrewd originates from PIE "skreu- 'to cut, cutting tool' (OED). Frequently, the first meaning of an adjectives is not 'clever' but 'sharp', which is the case with the following words: sharp Old English 'clever' goes back to PIE *sker-1 'to cut' (OED); smart XIV c. 'clever' (inf.) originates from PIE *smerd'pain' - "from the notion of 'cutting' wit" (OED); incisive XIX c. 'intelligently analytical, clear-thinking' originates from PIE *(s)kel-1 'to cut' (Watkins, 2000); acute XVI c., cute XIX c. 'clever' originate from PIE *ak- 'be sharp, pierce' (OED; Vaan, 2008, p. 23). Conversely, an unsatisfactory performance of the mind is associated with a blunt, useless instrument: nescient XVII c. goes back to PIE "ne 'not' and "skei- 'to cut, split, incise' (OED; Vaan, 2008, p. 545).

The typicality of interpreting the mind as a cutting instrument can be justified by the back semantic derivation, for instance, the aforementioned adjective keen, originates from PIE *gno- 'to know'. When this adjective first appeared in Old English, it encoded an abstract quality of intellect activity -'clever, wise, expert, skillful', but later, in the XIII c., the word commenced to denote a perceivable quality of an object - 'having a sharp edge or point' (OED; Barnhart, 1988). 
The degree of understanding something can be represented as the depth of penetration into a container: deep XIII c. 'of penetrating mind, having the power to enter far into a subject' goes back to PIE *dheub- 'deep, hollow' (OED; CODEE).

It is apparent that other cognitive models should participate in the interpretation of mental and moral qualities and these models, as well as their productivity, are still to be revealed. This is proved by the results obtained by Allan (2008) who investigated adjectives denoting human intellectual qualities in terms of identifying source domains for conceptual metaphors and metonymies for cleverness and stupidity (36 source domains were discovered).

\section{Results and Discussion}

So far, we have shown that the conceptual basis of an adjective can be unearthed via addressing its etymological data. It should be mentioned that an old root denotes an action, feature, or thing in the most general manner and can correlate with diverse frames, whose perspective affects the evaluation conveyed by adjectives. To flesh this out, let us bring in some examples. If the content of the container implies some knowledge and a cutting instrument implies the mind, the quality 'sharp' is considered positive and therefore the adjective develops a positive meaning: cute 'clever' goes back to PIE *ak- 'be sharp, pierce' (OED; Vaan, 2008, p. 23). In cases where a container refers to another person's mind and penetration occurs to deceive the person, the quality 'sharp' acquires a negative evaluation: cute 'cunning'. The phenomenon of polar evaluation meanings of one and the same word is referred to as enantiosemy. It is by no means a rare case in the language system, and additional examples may be cited. Similarly, the adjective nice possesses several opposite evaluation meanings: besides 'foolish, stupid' XIII c. and 'kind, good-natured, thoughtful' XIX c. belonging to the scope of this study, the word evolved the meanings of 'timid', 'fussy', 'delicate', 'precise, careful', and 'agreeable, delightful' (some of them have become obsolete and remain only in idioms and set expressions). Regarding nice, Weekley (1967) states, "The sense development has been extraordinary, even for an adjective" (p. 983). All these meanings arose due to the adjective's correlation with different frames, i.e. different situations where the adjective is applicable. The word nice originates from PIE *ne- 'not' and "skei- 'to cut, split' and literally means 'not to cut'. If a blunt instrument targets an object, it fails to cut it, which metaphorically indicates the situation when the mind, not sharp enough, fails to pierce into a new domain of knowledge; hence the negative meaning 'foolish, stupid' emerges. If a dull instrument directs a person, it cannot injure anyone, which metaphorically indicates a situation when someone's behavior or words do not hurt people's feelings; hence the positive meaning 'kind, good-natured, thoughtful' forms.

The concept of CONTAINER and its conceptual constituents can be represented explicitly through the components of a compound adjective. The first element of an adjective codes such peculiarities of a container as size, depth, substance, and indestructibility, to name but a few. The head element of a compound, i.e. the second one, denotes 'a container': -head, -skull, -pat, -brain, -mind, -thought, -think, -wit, -heart. Note that -thought and -think imply states, which are seen as containers, while brain, mind and wit are interpreted as "the seat of intelligence" (OED), i.e. the container including intelligence.

It is common knowledge that a larger container can hold more, metaphorically - more kindness, sympathy or intelligence, while small containers imply the presence of small quantities, for example: long-headed XVIII c., big-hearted XIX c., highbrow XIX c., high-browed XX c.; shallow-hearted XVI c., shallow-brained XVI c., shallowheaded XVII c., shallow-witted XVII c., shallow-minded XIX c., shallow-thoughted XIX c., small-minded XIX c., pinheaded XX c., lowbrow XX c. etc. The examples demonstrate that compound adjectives denoting intellectual qualities may consistently incorporate the same first element (eg. shallow-) and different head elements, which virtually are transnominations of mind (eg. -minded, -witted, -thoughted, -brained, -headed).

However, a large size appears to be ambiguous from the evaluation point of view: sometimes adjectives denoting high intellectual abilities acquire pejorative connotation like in egg-headed XX c. and pointy-headed $\mathrm{XX}$ c. Insofar as moral qualities are concerned, a large container may imply an excessive 'scope' of self-conceit, vanity, or arrogance: big-headed XX c., swell-headed XIX c., swollen-headed XX c. 
As mentioned above, a container may be characterized in terms of the substance it holds; the substance deficiency and its wrongness explain the malfunction of the mind, for instance: empty-headed XVII c., emptypated XIX c., empty-skulled XIX c., dull-witted XIV c., dull-headed XVI c. (for the etymology of dull, see above); air-headed XX c.; muddy-minded XVII c., muddy-brained XVII c., muddy-brained XVII c.; addle-pated XVIII c., addle-headed XVIII c., addlebrained XIX c.; wooly-minded XX c., meat-headed XX c., fat-brained XVI c., fat-witted XVI c., fat-headed XVIII c., and so forth.

A substance may also be characterized in terms of its weight and an unduly heavy or light substance indicates its inefficiency: thick-witted XVII c., thick-skulled XVII c., heavy-headed XVII c., light-minded XVI c.

The softness of a container's substance may convey opposite evaluations depending on whether it metaphorically represents cognitive abilities or attitudes to other people. In the former case, adjectives convey the negative evaluation of a mind's functionality: soft-minded XVI c., soft-brained XVII c., soft-pated XVII c., or soft-headed XVII c. Regarding moral traits, a gentle or soft heart can be easily touched by other people's misery, suffering, or sorrow, thus producing a positive evaluation: tender-hearted XV c., soft-hearted XVI c.

A solid container of stone, wood, bone, or iron lacks the interior space to hold anything; hence it fails to meet people's needs. Such a container metaphorically implies the absence of intelligence or kindness: hard-hearted XIII c., stone-hearted XVI c., blockheaded XVI c., ironhearted XVII c., timber-headed XVII c., wooden-headed XIX c., bone-headed XX c., etc. The root block originates from PIE *bhelg- 'a thick plank, beam' (OED). Interestingly, all compound adjectives based on the association with the quality of a container shell convey a negative evaluation, however, most of them initially lacked connotations and the negative figurative meaning applied to human beings developed much later, which is proved by the diachronic information recorded in dictionaries. For example, the primary, literal meaning of the adjective thickheaded XIX c. is "having a thick head", which is realized in biological terms like thick-headed mullet, thick-headed shrike (OED). The skull thickness of pachycephalosaurus motivated the coinage of its name "thick-headed lizard". Metaphorical meaning has also enriched the semantics of the following adjectives: pachydermatous XIX c., thick-skulled XVII c., thick-skinned XVII c., case-hardened XVIII c. At present, a person extremely sensitive to criticism or insults is disapprovingly referred to as thin-skinned (the primary meaning is 'having a thin skin').

Apart from that, mental and moral characteristics may be interpreted via temperature. It is common knowledge that human beings possess warm blood, which gave rise to reasoning metaphorically that warmth accounts for sympathetic pity and concern for the sufferings or misfortunes of others, while the absence of compassion and love is associated with cold: warm-hearted XVI c., cold-blooded XVI c., cold-hearted XVII c.

The interpretation of abstract human qualities through the CONTAINER image schema is one of the oldest; the first adjectives whose semantics was formed by this cognitive model date back to the Old English period (sharp 'clever', keen 'clever', hard 'showing no kindness or sympathy'); and still, the CONTAINER image schema participates in producing adjectival semantics in Modern English (unknowledgeable 1969, bubble-headed 1950s, airheaded 1972, pointy-headed 1972, etc.). It is noteworthy that the Old English adjectives are structurally simple, i.e. they include one root, and compound two-root adjectives are attested from the Middle English period.

The CONTAINER image schema underlying adjectival semantics may find reflection in phraseology and may influence the formation of the contexts where human intellectual or moral qualities are discussed. Here it is necessary to recall that Potebnya believed the closest etymological meaning of a word to help get a better understanding of its usage (Potebnya, 1926). For instance, the idiom "dull as ditchwater" directly refers to the substance of a container. The following contexts carry references to exterior containers - "Travellers are to be mindful of their surroundings" or to container substance - "What I said was very thoughtless" (MerriamWebster). So, to determine how the conceptual basis of adjectives affects their use in context seems a fruitful direction for further research.

\section{Conclusion}

This paper focused on modelling the conceptual basis of the semantics of English adjectives denoting human beings' abstract mental and moral qualities. To infer the conceptual basis, it was proposed that we consider 
etymological data about the adjectives in question to find out how these abstract qualities were interpreted at the moment of their nomination via a language sign. One of the ways to interpret mental and moral qualities is via the CONTAINER image schema, which seems to account for semantics and the evaluation meaning of the adjectives.

This study has shown that the CONTAINER image schema significantly contributes to this conceptual basis, accounting for $20 \%$ of the adjectives that were investigated. As mentioned above, this schema arises from the so-called embodied experience, which is important for interpreting such abstract human beings' qualities as mental and moral ones. The semantics of a word may be guided by any element of the CONTAINER image schema - INTERIOR, BOUNDARY, or EXTERIOR CONTAINER. In particular, a human's possession of knowledge and morality, or deficiency in them, may be associated with the fullness or emptiness of the container, the ability/inability to cross the container boundary, or an appropriate/inappropriate container substance.

In addition, the research has revealed that adjectival semantics may form on the basis of two integrated concepts, represented either by a root and an affix (in the case of derived adjectives) or by two roots (in the case of compound adjectives). Conceptual integration helps us encode various container characteristics.

The obtained findings also demonstrate that it is this image schema that predetermines the evaluation meaning of the adjectives, as evaluation meaning directly correlates with the particular characteristic of a container element. For example, the small size or hard shell of a container, or a thick or light container substance correlate with negative container value. Interestingly, a container characteristic may bear ambivalent value, for example, "soft", "hard", "large", or "cutting" can be estimated positively or negatively depending on the frame that incorporates the concept of CONTAINER (e.g. soft-minded, soft-hearted, big-headed). This enables polysemantic adjectives to comprise opposite evaluation meanings (e.g. nice, cute). This study has also shown that the CONTAINER image schema commenced to produce adjectival semantics as long ago as in the Old English period; and it can underlie semantics of structurally diverse words - primary, derived, or compound ones.

It goes without saying that cognitive models are not material things; their knowledge and exploitation are intuitive. However, it is this linguistic intuition that enables language speakers to coin innovations, enhance an adjective's semantics, and express an evaluation of people's qualities. Despite this, cognitive models underlying adjectival semantics do not exist as a separate language phenomenon, as they reflect ways that abstract human qualities are interpreted in English by correlating with conceptual metaphors, in particular, "Minds are containers" and "Ideas are objects". In some cases, this connection becomes apparent and is recognized by language speakers: She has a razor-sharp mind; He is an incisive critic; He is sharp-witted, He is hard-hearted, etc.

It could thus be assumed that the CONTAINER image schema affects adjectival semantics in different European languages. In order to compare its role in the interpretation of abstract human qualities among different languages, further research needs to be conducted.

\section{References}

Abd Rahim, N. (2013). Adjective identification in television advertisements. In Procedia - Social and Behavioral Sciences, 103, 86-94. https://doi.org/10.1016/j.sbspro.2013.10.311.

Alessandroni, N., \& Rodrigues, C. (2017). Is container a natural and embodied image schema? A developmental, pragmatic, and cultural proposal. Human Development, 60(4), 144-178. https://doi.org/10.1159/000478841.

Allan, K. (2008). Metaphor and Metonymy: A Diachronic Approach. Wiley-Blackwell.

Baker, M. (2003). Lexical categories: Verbs, Nouns and Adjectives. Cambridge University Press.

Barnhart, R.K., \& Steinmetz, S. (Eds.). (1988). The Barnhart Dictionary of Etymology. Wilson.

Berg, T. (2019). Adjective phrases with doubly modified heads: How lexical information influences word order and constituent structure. English Language and Linguistics, 23(2), 341-361. https://doi.org/10.1017/ S1360674317000430.

Bierwisch, M. (1983). Semantische und konzeptuelle Repräsentation lexikalischer Einheiten [Semantics and conceptual representation of lexical items]. In R. Růžička \& W. Motsch (Eds.), Untersuchungen zur Semantik 
(pp. 61-99). Akademie Verlag.

Bierwisch, M., \& Lang, E. (1987). Grammatische und konzeptuelle Aspekte von Dimensionsadjectiven [Grammatical and conceptual aspects of dimensional adjectives] (Vol. 26/27, pp. 1-28). Akademie-Verlag.

Bierwisch, M., \& Bosch, P. (1995). Semantic and Conceptual Knowledge. IBM Deutschland.

Boldyrev, N.N. (2016). Cognitive schemas of linguistic interpretation. Voprosy kognitivnoj lingvistiki, 4(49), 10-20. http://doi.org/10.20916/1812-3228-2016-4-10-20.

Chafe, W. L. (1970). Meaning and the structure of language. University of Chicago Press.

CODEE. (2003). The Concise Oxford Dictionary of English Etymology. Oxford University Press.

Cristani, M., Chitó, I., Tomazzoli, C., \& Zorzi, M. (2018). A sample algorithm for the lexical classification of comparable adjectives. Procedia Computer Science, 126, 626-635. https://doi.org/10.1016/j.procs.2018.07.297.

Croft, W. (2003). Typology and universals. Cambridge University Press.

Cruse, D. (2017). The lexicon. In M. Aronoff \& J. Rees-Miller (Eds.), The Handbook of Linguistics (pp. 235-255). Wiley.

Dancygier, B., \& Vandelanotte, L. (2017). Image-schematic scaffolding in textual and visual artefacts. Journal of Pragmatics, 122, 91-106. https://doi.org/10.1016/j.pragma.2017.07013.

Dixon, R. M. W. (1982). Where have all the adjectives gone? Mouton Publishers.

Dixon, R. M. W. (2004). Adjective classes in typological perspective. In R. M. W. Dixon \& A. Aikhenvald (Eds.), Adjective classes. A cross-linguistic typology (pp. 1-49). Oxford University Press.

Evans, V., \& Green M. (2006). Cognitive linguistics: An Introduction. Edinburgh University Press.

Gamkrelidze, T. V., \& Ivanov, V. V. (1984). Indoevropejskij yazyk i indoevropejcy [The Indo-European language and Indo-Europeans] (Vol. 2). Tbilisi University.

Gans, E. (1981). The Origin of Language: A Formal Theory of Representation. University of California Press.

Givon, T. (1970). Notes on the semantic structure of English adjectives. Language, 46(4), 816-837.

Givon T. (2014). On understanding grammar. Academic Press.

Hampe, B., \& Grady, J. E. (2005). From perception to meaning: Image schemas in cognitive linguistics. Mouton de Gruyter.

Hiramatsu K., Rulf K. E., \& Epstein S. (2010). When knowledge causes failure: Children's extension of novel adjectives and the interpretation of one. In Lingua, 120(5), 1209-1218. https://doi.org/10.1017/ S1366728917000232.

Hurtienne, J. (2017). How cognitive linguistics inspires HCI: Image schemas and image-schematic metaphors. In International Journal of Human-Computer Interaction, 33(1), 1-20. https://doi.org/10.1080/10447318.2016 .1232227.

Ioannou, G. (2018). Constructions and image-schema preservation. A historical-comparative analysis of PAY in Greek and English. Lingua, 206, 85-111. https://doi.org/10.1016/j.lingua.2018.02.001

Ivanov, V. V. (1992). Levyj i pravyj [Left and right]. In S.A. Tokarev (Ed.), Mify narodov mira. Encyclopeadia [Myths of the world's nations] (Vol. 2, pp. 43-44). Soviet Encyclopeadia.

Jackendoff, R. (2011). Conceptual Semantics. In C. Maienborn, K. von Heusinger \& P. Portner (Eds.), Semantics. An International Handbook of Natural Language Meaning (Vol. 1, pp. 688-709). Mouton de Gruyter.

Jespersen, O. (1951). The philosophy of grammar. Allen \& Unwin.

Johnson, M. (1987). The body in the mind: The bodily basis of meaning, imagination, and reason. University of Chicago Press.

Kacnel'son, S. D. (2001). Kategorii yazyka i myshleniya: Iz nauchnogo naslediya [Language categories and cognition]. Yazyki Slavyanskoj kul'tury.

Klimov, G. A. (1977). Tipologiya yazykov aktivnogo stroya [The typology of active-stative languages]. Nauka.

Kubryakova, E. S. (1999). Semantika v kognitivnoj lingvistike (o koncepte kontejnera i formah ego ob"ektivacii $\mathrm{v}$ yazyke) [Semantics from cognitive linguistics perspective (on the concept 'container' and its language representation)]. Izvestiya RAN. Seriya literatura i yazyk, 58(5-6), 3-12.

Kubryakova, E. S. (2008). Chasti rechi $v$ onomasiologicheskom osveshchenii [Parts of speech from the onomaseological point of view]. LKI.

Lakoff G. (1970). Pronominalization, negation, and the analysis of adverbs. In R. Jacobs \& P. Rosenbaum (Eds.), Readings in English transformational grammar (pp. 145-165). Wiltham.

Lakoff, G. (1987). Women, Fire, and Dangerous Things: What Categories Reveal About the Mind. University of Chicago Press.

Lakoff, G., \& Johnson M. (2003). Metaphors we live by. The University of Chicago Press.

Lang, E., \& Maienborn, C. (2011). Two-level Semantics: Semantic Form and Conceptual Structure. In C. Maienborn, K. von Heusinger \& P. Portner (Eds.), Semantics. An International Handbook of Natural Language 
Meaning (Vol. 1, pp. 709-740). Mouton de Gruyter.

LaTerza,I.(2015).Adjectives and determiners.Lingua, 168,85-103.http://dx.doi.org/10.1016/j.lingua.2015.09.007.

Martinez, I., Español, S., \& Pérez, D. (2018). The interactive origin and the aesthetic modelling of imageschemas and primary metaphors. Integrative Psychological and Behavioral Science, 52(4), 646-671. https://doi. org/10.1007/s12124-018-9432-z.

Maturana, H.R., \& Varela, F.J.(1992). The tree of knowledge: The biological roots of human understanding. Shambala Publications.

Meletinskij, E. M. (1976). Poetika mifa [The myth poetics]. Nauka.

Merriam-Webster (n.d.). Merriam-Webster dictionary online. An Encyclopeadia Britannica Company. http:// www.merriam-webster.com/

Nokolaeva I. (2008). Between nouns and adjectives: A constructional view. Lingua, 118(7), 969-996. https://doi. org/10.1016/j.lingua.2006.07.003.

OED. (1989). The Oxford English Dictionary (2nd ed.). The Clarendon Press.

Piaget, J. (1926). The Language and Thought of the Child. Routledge \& Kegan.

Podosinov, A. V. (1999). Orientaciya po stranam sveta $v$ arhaicheskih kul'turah Evrazii [Cardinal direction orientation in archaic cultures]. Yazyki Russkoj kul'tury.

Pokorny, J. (1959). Indogermanisches Etymologisches Wörterbuch [Indo-Germanic Etymology Dictionary]. http:// www.proto-indo-european.ru/dic-pokorny/iew-p.htm

Porohnickaya, L. V. (2014). Konceptual'nye osnovaniya ehvfemii v yazyke (na materiale anglijskogo, nemeckogo, francuzskogo, ispanskogo i ital'yanskogo yazykov) [The conceptual basis of euphemia in language: Analysis of English, German, French, Spanish and Italian] [Doctoral dissertation]. Moscow State Linguistic University.

Potebnya, A.A. (1968). Iz zapisok po russkoj grammatike [Some notes on Russian grammar] (Vol. 3). Prosveshchenie.

Potebnya, A.A. (1926). Thought and Language. State Publishing House.

Pustet R. (2006). Adjectives. In K. Brown (Ed.), Encyclopedia of Language \& Linguistics (2nd ed., pp. 60-63). https:// doi.org/10.1016/B0-08-044854-2/00282-0.

Ratkus, A. (2018). This is not the same: The ambiguity of a Gothic adjective. Folia Linguistica Historica, 52(539-2), 475-494. https://doi.org/10.1515/flih-2018-0017.

Roget, P. M. (1987). The Original Roget's Thesaurus of English Words and Phrases. Longman.

Schuchardt-Brevier, H. (1928). Ein Vademecum der allgemeinen Sprachwissenschaft [A vademecum of general linguistics] (2nd ed.). Niemeyer.

Senkbeil, K. (2017). Image schemas across modes and across cultures: Communicating horror in Philip Roth's Nemesis and Ridley Scott's Alien. Language and Literature, 26(4), 323-339. https://doi. org/10.1177/0963947017739741.

Sosnina, A. (2015). Semantic relations of the adjective 'empty' in Modern English language. Procedia - Social and Behavioral Sciences, 200, 531-536. https://doi.org/10.1016/j.sbspro.2015.08.017.

Trotzke, A., \& Wittenberg, E. (2019). Long-standing issues in adjective order and corpus evidence for a multifactorial approach. Linguistics, 57 (2), 273-282. https://orcid.org/0000-0002-3943-4282.

Vaan, de M. (2008). Etymological Dictionary of Latin and the Other Italic Languages. Brill.

Vernillo, P. (2019). The role of the image schema in the analysis of the semantic variation of action verbs. Data from IMAGACT. CEUR Workshop Proceedings, 2347. http://doi.org/urn:nbn:de:0074-2347-1.

Watkins, C. (2000). The American Heritage Dictionary of Indo-European Roots. HMH. http://www.proto-indoeuropean.ru/dic-watkins/ier-p.htm

Weekley, E. (1967). An Etymological Dictionary of Modern English (Vol. 2). Dover Publications.

Weicker, M., \& Schulz, P. (2019). Red train, big train, broken train: Semantic aspects of adjectives in child language. Language Acquisition and Language Disorders, 63, 203-221. https://doi.org/10.1075/lald.63.11wei.

Wierzbicka, A. (1996). Semantics: Primes and Universals. Oxford University Press.

Zhirmunskij, V.M. (1976). Obshchee i germanskoe yazykoznaniev [General and Germanic linguistics]. Nauka.

Zykova I.V. (2018). Synesthesia in the process of phraseologism-formation: A new approach. Yearbook of Phraseology, 9(1), 85-110. http://doi.org/10.1515/phras-2018-0006. 